\title{
Jewish inspiration of Christian catacombs
}

\section{A Jewish cemetery in ancient Rome harbours a secret that bears on the history of early Christianity.}

The famous catacombs of ancient Rome are huge underground cemeteries, of which two Jewish catacomb complexes of uncertain age and 60 early-Christian catacombs have survived $^{1-3}$. Here we use radiocarbon dating to determine the age of wood originating from one of the Jewish catacombs and find that it pre-dates its Christian counterparts by at least 100 years. These results indicate that burial in Roman catacombs may not have begun as a strictly Christian practice, as is commonly believed ${ }^{1,3,4}$, but rather that its origin may lie in Jewish funerary customs.

The Jewish and Christian catacombs of Rome are all thought to date from the same general period - namely, from the early third century through to the early fifth century $\mathrm{AD}$ (refs 2,5) - but more precise dating has been difficult ${ }^{5}$. We therefore collected organic material for radiocarbon dating that had been incorporated during the construction of grave recesses (loculi) in the Jewish Villa Torlonia catacomb ${ }^{89}$ (Fig. 1, and see supplementary information).

Each loculus was sealed by a small wall of rubble and bricks that was covered in a smooth layer of lime. Pieces of charcoal from the limekiln that had been embedded in the lime were collected for dating. As young trimmings would have been the preferred wood for generating the high temperature (around $900{ }^{\circ} \mathrm{C}$ ) necessary to effect the conversion of limestone to lime, we consider that contamination from mature or already dead wood is unlikely.

Fifteen samples from the five interconnected regions (A-E in Fig. 1) that make up the catacomb were subjected to radiocarbon analysis by atomic-mass spectroscopy ${ }^{10}$; absolute ages were determined for $2 \sigma$ ranges by using the computer code Calib4 (ref. 11). Results from five damaged samples had to be discarded, but preliminary analysis of the remainder looked promising ${ }^{12}$.

Our analysis reveals a complete construction history of the upper and lower catacombs. The sequence of $2 \sigma$ calendar ages ranges from $50 \mathrm{BC}$ (from a sample at the entrance area to the lower catacomb) to $\mathrm{AD} 400$ (sample from region $\mathrm{A}$ in the upper catacomb) (see supplementary information). Various charcoal samples were systematically identified as being derived from taxaknown to be growing in the area during the time of the catacomb's construction ${ }^{13}$ (see supplementary information).

Our results are consistent with the chronological layout of the catacomb (Fig. 1). The

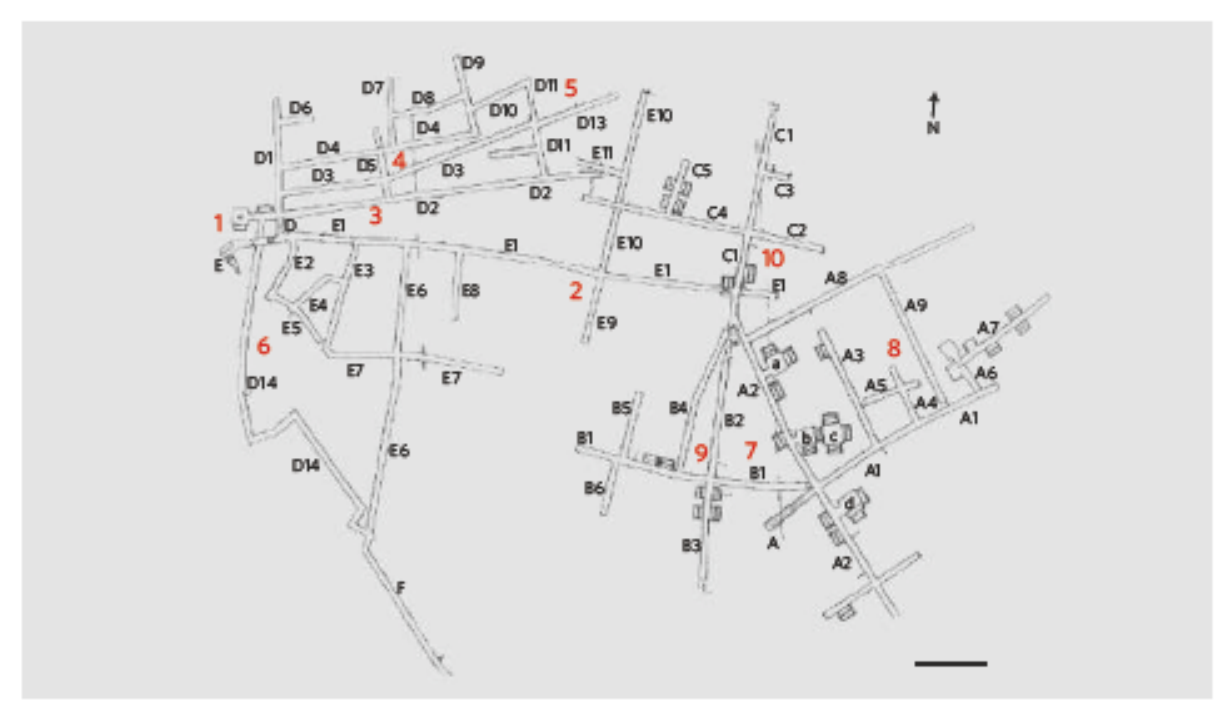

Figure 1 | Layout of upper and lower Jewish catacombs in Villa Torlonia in Rome. For radiocarbon dates of samples taken from different construction sites, see supplementary information. Numbers refer to the sample origin; letter-number combinations refer to gallery number. Scale bar, $10 \mathrm{~m}$.

oldest sample (number 1) derives from the entrance, the earliest construction point. Samples 3-6 from the D region fit the topographical development of the catacomb; the age of a painted arcosolium (arched grave) in the upper catacomb (sample number 7) is consistent with dating proposed on the basis of its style (AD 320-350; ref. 5;). The only sample that does not fit our chronology is number 10 , which originates from a gallery that was dug into a pre-existing network of underground water tunnels.

This evidence indicates that the Villa Torlonia catacomb came into use in the second century $\mathrm{AD}$, a century before the building of the earliest Christian catacombs started. Given that Roman Christianity evolved from Judaism, and Jews and Christians continued to interact until well into Late Antiquity, it is possible that Christian funerary practices were influenced by Jewish ones. This could explain the similarity between the oldest of the early Christian underground cemeteries and the Jewish Villa Torlonia catacomb, particularly considering that Callixtus, the deacon in charge of developing the Christian catacombs, came from the Jewish quarter. However, confirmation awaits radiocarbon dating of the Christian catacombs.

Leonard V. Rutgers ${ }^{\star}$, Klaas van der Borgt,

Arie F. M. de Jongt, Imogen Pooleł

*Faculty of Theology, Utrecht University,
3508 TCUtrecht, The Netherlands e-mait: Intgers@theo.uu.nl †AMS Facility Utrecht, Subatomic Physics Department, Utrecht University, 3508 TAUtrecht, The Netherlands †National HerbariumNederland, Utrecht University Branch, 3585 CS Utrecht, The Netherlands

1. Fiocchi Nicolai, V.\& Bisconti, F. \& Mazzoleni, D. The Christian Catocombs of Rome: Histary, Decarations, inscriptions (Schnell and Steiner, Regensburg 1999).

2. Rutgers, L.V.Subterranean Rome(Peeters, Leuven, 2000).

3. Fiocchi Nicol ai, V. Strutture Funerari ed Edifid di Culto Paleo oistani di Rama dal IV al VISecolo(Pontificia Commissione di Archeologia Sacra, Vatican City, 2001).

4. Pergola, P. Le Catocambe Ramane. Stonia e Tapografia (Nuova Ita lia Editrice, 1997).

5. Rutgers, LV. The Hidden Heritage of Dlaspara Judaism (Leuven, Peeters, 1998).

6. Guyon I Boreas 17, 89-103 (1994)

7. Declers, IG.Studid Antichith Cristiana 48, 217-238(1992)

8. Fasola, U. M. Rlvistadi Archealogia Cristiana 52, 7-62 (1976).

9. Barbera M. \& Magnani Cianetti, M. in I Beni Cultuall Ebrici in Italla. Situazione Attuale, Prablem, Prospetthe e Progetti per if Futuro (ed. Perani, M) 55-70 (Longo Editore.

Ravenna, 2003).
10. van der Borg, K et al. Nucl. Instr. Meth. B 123,97-101 (1997).

11. Stuiver, M. \& Reimer, P. I Rodiocarbon 35, 215-230 (1993).

12. Rutgers, L.V van der Borg, K.\& de long, A.F.M. Radiocirbon 44, 541-547 (2002)

13. Fenaroli, L.GWAAlberi doltalla (Aldo Martello Editore, Milan, 1967)

Supplementary information accompanies this communication on Nature's website. Competing fin ancial interests: declared none. doi:10.1038/436339a 